Alma Mater Studiorum - Università di Bologna DEPARTMENT OF ECONOMICS

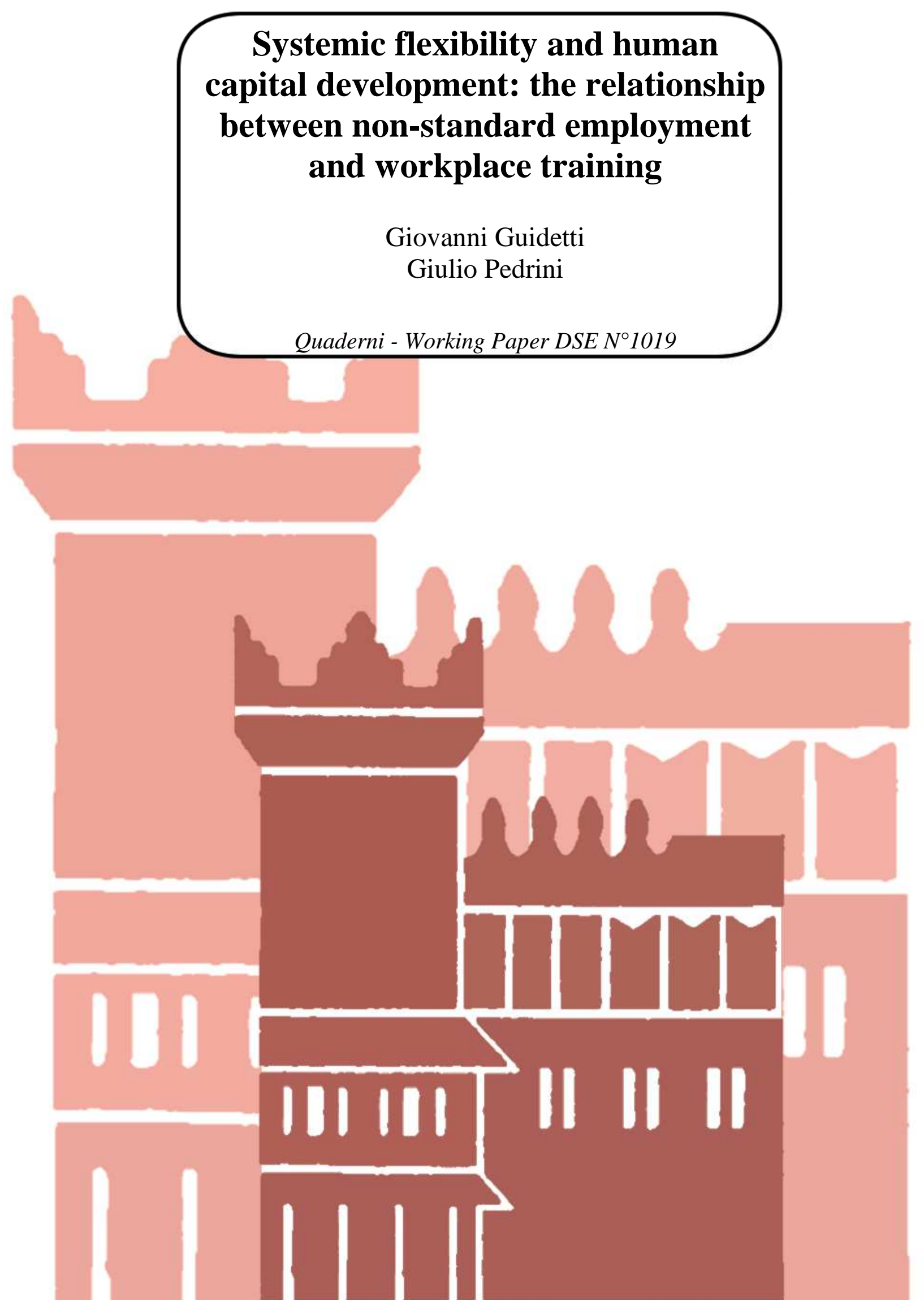




\title{
Systemic flexibility and human capital development: the relationship between non-standard employment and workplace training."
}

\author{
Giovanni Guidetti ${ }^{\dagger} \quad$ Giulio Pedrini
}

\begin{abstract}
The aim of this paper is to explore the relationship between non-standard contracts (part-time, fixed-term) and workplace training by discussing the implications of two different theoretical frameworks grounding on human capital theory and strategic management, respectively. To achieve this purpose we develop alternative hypothesis on the association between the presence of nonstandard workers and four different outcome variables related to workplace training and job-related practices. By using data on Italian firms we get different results according to the type of nonstandard contract and training. Part-time and temporary contracts carry out distinct functions with respect to off-the job training as far as labour flexibility is concerned. On the other hand, although non-standard work seems to be unrelated to on-the-job training decisions, this is not the case when the overall number of job-related practices is taken into account. Overall, our evidence can reflect the decision to substitute off-the-job training with job-related practices in presence of part-time workers. Conversely, the recourse to temporary employment can be associated with the need to enhance systemic flexibility throughout the organization.
\end{abstract}

Keywords: training, non-standard employment, human capital, flexibility

JEL classification codes: J24, M53, M54

\footnotetext{
* We are very grateful to Kate Purcell and Wiji Arulampalam for their useful insights and suggestions. We also thank the participants to the $9^{\text {th }}$ Conference of the Italian Association of Law and Economics (SIDE) held in Lugano on December 12-13, 2013. Usual disclaimers apply.

† Department of Economics - University of Bologna. g.guidetti@ unibo.it

$¥$ Inter-university Research Center for Public Services. giulio.pedrini3@unibo.it
} 


\section{Introduction}

In the last two decades, in parallel with the acknowledgement of the increasing importance of training and human capital in fostering the goals of economic progress, and social integration, European countries have realized labour market reforms aiming at fostering the diffusion of flexible contracts as a mean to increase the employment rate. Italy has also entered this reform process. From the early nineties onwards extensive labour market reforms has been implemented, leading to a wider use of temporary and part-time contracts, and eventually to a two tier employment protection regime that relaxes regulation on the use of temporary contracts, while maintaining stringent employment protection rules for permanent contracts. This has led to the increase in the share of temporary and part-time work, which is a type of non-standard employment that is likely to be associated with unskilled jobs, low wages, and poor career perspectives (Connoly and Gregory, 2008; Manning and Petrongolo, 2008; Fernández-Kranz and Rodríguez-Planas, 2011), while its effects on job and life satisfaction is quite puzzling (Booth and Van Ours, 2008). Moreover, it can be considered as temporary to the extent that employees are not willing to maintain this regime during their future working life (Barrett and Doyron, 2001).

However, this transition may have negatively affected training decisions due to inferior incentives to invest in human capital attached to flexible contracts because of the limited expected payback period for that investment. For the same reason, precarious workers are inhibited to actively participate to training programs and achieve the expected learning outcomes.

On the theoretical ground one can state that two distinct approaches have been developed for the analysis of the interactions between training and firms' requirement of flexibility. The first and dominant approach, at least in the domain of economics, is rooted in the human capital models and in their derivations and developments. The focus of these models is mainly on the conditions and the incentives which favour the financing of employees' training by the employer and/or by the employees themselves. In these models labour flexibility plays a key role as it affects the expected tenure of employees and, in this way, the time needed to pay back employers' investment in training. The second approach is based in the strategic management view of the firm. In this perspective, the firm is conceived as a complex system in which each personnel practice interacts with the others and can be understood only when one takes into account the cobweb of relationships among different practices. Accordingly, training practices interact with labour flexibility measures and this complex structuring affects the employers' choices.

An extensive strand of empirical literature has explored the relationship between flexible contracts and training investments both in Europe and in Italy from the supply-side, using information on household and individual workers, while few studies have investigated this effect from the labour 
demand standpoint, using data at firm level. Conversely, few studies have investigated this effect from the labour demand standpoint, using firm-level data, despite the fact that the key decision maker for firm personnel and training policy is the employer, who usually finance the relevant investment and may constrain workers in their training choices. Moreover most of these studies often nest together on-the-job and off-the-job training due to the unavailability of separate data. Yet, these two types of training are different in nature. We try to fill this gap with respect to the Italian context by estimating off-the-job and on-the-job training determinants through firm-level data. The presence of part-time and temporary workers represents the flexibility measures mentioned above and, therefore, the explanatory variables of our models. We are going to discuss these issues developing and testing a set of hypotheses stemming directly from these two theoretical approaches. The rest of the paper is organized as follows. Section 2 highlights the increasing role of nonstandard employment in the Italian labour market. Section 3 reviews both theoretical and empirical literature on the relationship between temporary work, part-time and training, with particular reference to the literature based on human capital. Section 4 develops the theoretical framework based on the strategic management approach. Section 5 discusses the different hypotheses about the relationships between training and flexibility, which can be worked out within the two distinct theoretical models. Section 6 presents the dataset and the descriptive statistics. Section 7 justified the econometric models. Section 7 shows and discusses the result. Section 8 concludes.

\section{Labour market reforms and non-standard employment in Italy}

Italy has been fully involved in this process. From the early nineties onwards extensive labour market reforms have been implemented. Further to the enactment of laws 196/1997, $368 / 2001$ and 30/2003, the pre-existing rules that had limited the use of fixed-term contracts were substantially relaxed. The same reforms allowed employment via manpower agencies, and introduced other types of non-standard contracts. The overall change was substantial: according to OECD (2004), Italy is the country that experienced the highest relaxation of legislation on temporary contracts between the late 1980s and 2003. This reformatory process led to a wider use of temporary and part-time contracts and eventually to the adoption of a two-tier employment protection regime. The share of fixed-term contracts rose from $10.2 \%$ to $13.4 \%$ of the employees between 1993 and 2011, while the share of part-time employees increased from $9.7 \%$ to $15.0 \%$ in the same period. The fact that most of part-time workers are women $(27.9 \%$ of total female occupation in 2009) does not mean that this contractual form is always voluntary. Actually, the share of part-time female employees unwilling to stay in this condition has always been fairly high (around $35 \%$ ) in the last decade, eventually rising to 55\% in 2012. Notably, in most recent years the 
growth of part-time work has only concerned the non-voluntary component which is typically penalized in terms of both wages (Barret and Doiron, 2001) and job satisfaction (Berton et al, 2009). Currently, this percentage is much higher than the EU average (around 25\% in 2012), despite the lower share of part-time contracts registered in Italy.

In parallel, Italy has recorded a serious slowdown of labour productivity growth which has systemically lagged the average of EU-15. Comparing the periods 1990-1994, 1995-1999 and 20002005, we notice that the yearly rate of growth of value added per hour worked was declining for Italy slowing from $1.55 \%$ to $0.31 \%$ from $1990-1994$ to $1995-1999$ and dropping to $-0.07 \%$ in 2000 2005. In the same periods the average data of EU-15 has decreased from 1.88\% in 1990-1994 to $0.98 \%$ in $2000-2005$, meaning that the yearly relative gap with Italy augmented from $0.33 \%$ to $1.05 \%$. The same result is reached by comparing Italy with the other major European countries: Germany, France and United Kingdom. In most recent years Italian situation even worsened. In the period 2000-2012 total factor productivity in Italy has remained substantially stable, showing disappointing trajectories. One explanatory argument for this productivity drop has been the introduction of a flexible market regime not accompanied by institutions that provide workers with training during the transition phase from one job to another one (active labour policies). Flexible employment may undermine long-run economic performance if it is not associated with additional incentives or subsidies to training investments. Accordingly, labour market segmentation has been called to have a negative impact on training activity due to the higher job instability of non-standard workers. On the other hand, however, dual labour markets may stimulate a better coordination of the workforce and provide suitable institutional frameworks for the firms to maintain a proper balance between the different dimensions of flexibilities under the assumption that benefits will arise only if a systemic approach is taken.

\section{Training investments and non-standard workers in the human capital literature}

One of the main threats attached to flexible employment is that it can lead to firms' underinvestment in human capital. According to the standard prediction of human capital theory a high-rate of non-standard contracts negatively affects employers' attitude to provide specific training (Becker, 1964) as workers are expected to experience a relatively high turnover rate. This has economic consequences on firm's behaviour. The expectation that employees will leave the workplace lowers the capability for the firms to capture most of the benefits accruing from training (Beckman, 2002). In turn, workers have a lower incentive to actively participate to training programs and achieve the expected learning outcomes. This argument applies in particular to temporary and involuntary part-time workers. Part-timers are also expected to receive less training 
than their full-time counterparts since they have a shorter post-training period for enjoying the returns from training.

In presence of imperfect labour markets (Katz and Ziderman, 1990; Acemoglu and Pischke, 1999) this argument can be applied to general training as well. Market imperfections, such as monopsony power, asymmetric information, unions, mobility restrictions and minimum wages, create a wedge between the worker's productivity inside the firm and his outside options. This wedge provides employers with incentives in investing in general training and is likely to increase in parallel with the workers' skill level. A similar outcome is achieved in presence of a mixed training intervention that allows the firm to partially recapture its general training outlays thanks to the "hold up" problem arising from the simultaneous presence of specific skills (Kessler and Luelfesmann; 2006). The same occurs if technical complementarities between general and specific human capital (Brunello, 2001) and/or between training and innovation (Acemoglu, 1997) are assumed. The presence of complementary investments in general training thus generates a larger increase in productivity and better economic performance (Barrett and O'Connell, 2001; Dearden et. al., 2006) than separate investments in specific training. However, even under these approaches, substantial differences between general and specific training persist. In particular, the expected payoff of general training is usually higher in the long term rather than in the short term.

According to this theoretical framework, fixed-duration and involuntary part-time workers are expected to experience a relatively high turnover rate, for firms it would be difficult to recoup training costs and provide incentives for an appropriate learning process for these workers. In turn, the firm's return from training investments is negatively related to the probability that workers quit the firm, under the assumption that the effects of training on productivity comes out only at the end of the intervention. Thus, employers are supposed to reduce their training investments as long as the share of temporary and part-time workers is high. Eventually, these workers will achieve lower level of productivity than permanent ones due to the limited amount of training they receive. The aim of promoting flexibility may therefore be not compatible with the aim of improving workers' skills in the workplace as the market is likely to end up with a high quit-low training equilibrium.

Concerning empirical evidence, most of the existing studies support the view that workers with open-ended contracts are more likely to receive training than non-standard ones. Notably, assuming that both off-the-job and on-the job training are paid by employers (Booth and Bryan, 2002; OECD, 2003) there is evidence of firms' under-investment in training for both part-time and temporary employees. Oosterbeek (1996) finds that Dutch workers with permanent contracts have higher training probabilities than temporary workers. More recently, Fouarge et al. (2012) confirm these results, also reporting that, among workers that receive employer-funded training. Those who 
have a non-standard contract are more likely to receive general training than permanent ones. Likewise, O'Connell and Byrne (2012) find that Irish temporary and part-time workers are moderately penalized with respect to general training, but part-time employees are more likely to receive specific training than full time ones. With respect to Britain, Arulampalam and Booth (1998) show that workers with temporary contracts are less likely to be trained in the workplace using household data, while Addison and Bielefeld (2004) find similar effects for part-time contracts employing firm-level data. These results are partially confirmed by Boheim and Booth (2004), but negative effects are limited to some categories of workers (female non-manual workers). Almeida-Santos and Mudford (2004) analyse the determinants of employer-provided training in Australia using workplace level information, finding out that both part-time and fixed term employees are less likely to be trained. Employing household data, Forrier and Sels (2003) find that Belgian permanent employees are more likely to receive employer-funded training than temporary employees. Similar findings are reported for Spain (Albert et al., 2005; Cabrales et al., 2014) and Germany (Sauermann, 2006). These results are indirectly confirmed by another strand of literature that focuses on the (negative) impact of temporary employment on labour productivity (Dolado and Stucchi, 2008). Fewer studies report the absence of significant training penalties for temporary workers (Oosterbeek, 1998).

Comparative analyses generally confirm the negative correlation between training opportunities and non-standard workers in European countries (Bassanini et al., 2005; European Commission, 2010; OECD, 2002). Yet, they show a statistically significant lower training probability for temporary and part-time workers with respect to a limited number of countries (Arulampalam et al., 20034; Albert et al., 2010 $)$, while the impact of apprentices has been related to the level of institutional support provided to this type of contract, which is higher in Germany, Austria and Switzerland than in Anglo-Saxon countries (Dustmann and Schonberg, 2012). However a negative correlation also emerges from the relationship between training incidence and the overall level of employment protection, suggesting that training investments are particularly poor in presence of a combination of high employment protection and a wide recourse to non-standard employment contracts. Overall, cross-country comparisons report that training levels mainly diverge for the different weights attached to worker and job characteristics rather than for the

\footnotetext{
${ }^{4}$ In particular, temporary male workers have a lower probability to be trained in Austria, Britain, Denmark, Finland and Spain (for the overall sample results are only significant for Danish workers), while part-time workers (both males and females) are less likely to be trained in Britain and Finland.

${ }^{5}$ In particular, temporary workers have a lower probability to receive training in Spain and Britain, while for part-time results are never significant.
} 
different characteristics of workers and jobs between the selected countries (Leuven and Oosterbeek, 1999).

However, most of these studies rely on supply-side information grounding on micro data on household and individual workers. Conversely, few studies have investigated this effect from the labour demand standpoint, using firm-level data, despite the fact that the decision whether to train or not rests mainly on the employer, who usually finance the relevant investment. Most of the existing analysis is therefore partially biased by the measurement error attached to the distance between employers' and employees' responses regarding the provision of informal training and the intensity of formal training.

\section{Flexibility as a multidimensional concept}

The use of the notion of flexibility among economists has been quite unilateral in the standard economic literature and has not advanced further since Atkinson's (1985) discussion of three aspects of labour flexibility: a) numerical flexibility; b) wage flexibility and c) functional flexibility. One of the limits of this analysis of flexibility is that each of these aspects of flexibility is analysed separately, without taking into account how these three dimensions of labour flexibility can be interrelated through relationships of either trade-off or complementarity.

A more thorough analysis of flexibility, which works out a complex framework of analysis based on a systemic view of the firm, can be found in the strategic management literature (Volberda, 1998). The starting point of Volberda's analysis is the recognition of the existence of a paradox of flexibility. The pursuit of flexibility in a firm can be achieved by the balance between two diverse kinds of capabilities. On the one hand there is the option of consolidating and exploiting the present productive practices and procedures (conservative flexibility) in order to maximise profits; on the other hand there is the option of reconceptualising and radically changing the norms, the paradigms and the cognitive structure on which the firm's operations are based in order to face drastic, and often unforeseen, business environment changes and to create new and unexplored business opportunities (innovative flexibility) ${ }^{6}$. There is a substantial difference between conservative and innovative flexibility. The former entails reactions and change well within the same productive paradigm, either through a more efficient implementation of existing practices and procedures or through the introduction of new ones without significant changes in distinct competences. This is perfectly consistent with a tendency towards conservatism and ossification. The latter implies the abandonment of old practices and routines through the development of a new vision and conception of the business and the consequent introduction of new knowledge and experiences (Argyris and

\footnotetext{
${ }^{6}$ The designation of conservative and innovative flexibility is ours.
} 
Schon, 1978). In this case flexibility presupposes a thorough evolution of both the technoorganisational framework and the capability to manage and control this radical process of change. The balance between these two different concepts of flexibility is a key to advance the firm's competitiveness. It is important to emphasise that the notion of a balance between innovative and conservative flexibility does not mean that these two forms of flexibility have to maintain a specific and constant ratio measured with some statistical indicator. The idea is that flexibility is made up by these two components and that the operation and the performance of a firm also depend on how these two components combine. However, there is not "one best combination" but simply different approaches characterised by the different relevance acknowledged to each form of flexibility. Certain firms can find it profitable to give priority to conservative flexibility, whereas others can prioritize innovative flexibility.

Consistently with this framework of analysis, Volberda discusses all the different approaches and definitions of flexibility which can be found in the strategic management literature. As the paradox of flexibility refers to the tension between conservative and innovative flexibility, we can observe that flexibility is a multidimensional notion. Each dimension captures a specific aspect of flexibility and is complementary to the other dimensions. For our purposes it can be useful to introduce three notions of flexibility, each one corresponding to a specific dimension: a) internal and external flexibility; b) operational, organisational and strategic flexibility; and c) short-term, medium-term and long-term flexibility ${ }^{7}$.

Each notion captures and defines flexibility according to a specific perspective and should be combined with the others. Hence, any measure aimed at reinforcing flexibility should be compared to each of these three dimensions, in order to properly assess its impact and to understand whether its target is either conservative or innovative. Therefore, the introduction of a specific measure can be considered as a tool to address a specific combination of these three dimensions of flexibility ${ }^{8}$.

Moreover, what are really important to assess the policies for flexibility of a firm are not only the distinct measures considered individually, but also the interactions among the practices and their effects on the balance between conservative and innovative flexibility. This balance favours the

\footnotetext{
${ }^{7}$ Whereas dimensions sub b) and c) are quite well known, it is worth specifying the meaning of both internal and external flexibility. Internal flexibility refers to the capability of a firm to adapt and react to changes in the business environment but also to pre-empt and anticipate possible changes. External flexibility refers to the capability of firms to influence the external environment through either protective or offensive measures. For more details, see Volberda (1998).

${ }^{8}$ For example if the firm decides to hire temporary workers, this is a measure which affects internal flexibility because it increases the ability to react to changes in the level of demand (first dimension). Furthermore, this measure can be considered as a tool to reinforce operational flexibility, since it implies a change in the level of activity without any transformation in the organisational structure (second dimension) and, finally, a measure aimed at strengthening shortterm flexibility (third dimension).
} 
continuity in productive activities and the preservation of core competences, without hampering the pursuit of the evolution of new ideas, the introduction of new practices, procedures and core competences and the turnover of obsolete or redundant competences. In this sense, flexibility is a systemic characteristic of a firm, which can be assessed only by taking into account the complex set of choices made by the management. If a sustainable balance is not reached and maintained the result could be either an increase in rigidity, if measures aimed at increasing conservative flexibility prevail, or chaos and disorder, if specific manoeuvres to foster innovative flexibility outweigh measures addressing conservative flexibility. The requirement to reach and keep such a balance can be met through a bundle of interventions.

Conclusively, the target of these interventions affecting flexibility is twofold. On the one hand their goal can be simply to support and promote a specific dimension of flexibility. On the other hand their aim can be the preservation of the balance between innovative and conservative flexibility. Additionally, even though these dimensions of flexibility are distinct, complementarity relationships can be observed among them so that, when a certain measures is introduced, further interventions could be required in order to favour the viability (effectiveness) of this measure and to maintain the balance between conservative and innovative flexibility.

This multidimensional concept of flexibility helps us to understand that the relationship between labour flexibility and training investments is not as straightforward and unidirectional as we could expect. The strategic management approach suggests that training decisions could be complemented by other interventions on labour flexibility in order to maintain the balance between conservative and innovative flexibility or to enhance the effectiveness of the measure itself or to minimise some undesired side effects. However, the two approaches are not alternative to one another, because their theoretical implications do not contradict each other. They provide two diverse perspectives for the analysis of the effects of interventions on labour flexibility. In Atkinson's approach a microeconomic perspective prevails and the unit of analysis is the single worker. The focus is on how each measure affects the three dimensions of flexibility and their interactions on the basis of the effects of each measure on the single worker. In the systemic approach the focus is on the relationships among different practices and their effects on workers. In conclusion, these two approaches can integrate one with the other so to provide a thorough analysis of the effects of interventions on labour flexibility.

\section{Training, complementarity and flexibility}

Distinguishing between off-the-job and on-the-job training 
Workplace training can be viewed as a dynamic process of specification of complementary relationships between skills and other inputs. The provision of different skills is therefore an important element in the economic analysis of training and its determinants, while training interventions accomplish different functions within the firm in coping with skill development among the workforce according to their composition in terms of methods and contents. Thus, in view of their different nature and purpose, training initiatives need to be distinguished according to their nature as long as the availability of data makes it feasible.

The standard economic literature identifies two dichotomous types of training in relationship to the corresponding skills that are developed among employees: general and specific training. General training is defined in terms of transferability. The attached skills can be of use to both current and future employers. On the other hand, only the current employer can get benefits from specific training. Moreover, the provision of specific skills, together with the straight practical applications in the accomplishment of the job tasks, is expected to increase labour productivity more quickly, but also to shorten the pay-back period due to skills' higher rate of obsolescence, particularly in presence of frequent technical changes. Both of them, however, are mainly financed by the employer (Evertsson, 2004; Fouarge et al., 2013).

In parallel, training can be distinguished between off-the-job and on-the-job training. Off-the-job training is undertaken away from the work position and includes both the formal component of internal training such as dedicated courses, and the whole external training. Internal courses mainly deal with technical contents that can be considered as either industry-specific or firm-specific. On the other hand, although it is not possible to exactly separate the general component from the specific one in each training intervention, we can assume that external courses are more likely aimed at developing general skills. Therefore, we can claim that off-the-job training can be referred to both general and specific skills. These skills however are not equally distributed. According to existing studies general training usually prevail (Booth and Bryan, 2002; O'Connell and Byrne, 2012).

On the other hand, on-the-job training takes place during working hours, very often in informal way, and is expected to be primarily specific. The range of on-the-job training is rather wide. It includes the learning of sophisticated techniques, developed in-house, but also the acquiring of specific knowledge related to menial tasks (e.g. the use of a photocopy machine). For its nature the incidence and intensity of on-the-job training are severely affected by the rate of obsolescence of specific skills. On-the-job training can be, however, quite informal, not systematic and difficult to measure and to monitor. Such characteristics can hamper the possibility to measure its actual intensity and bring about an underestimation of its effects on labour productivity (Nordman and 
Hayward, 2006). For this reason in most of the empirical studies on-the-job training is usually measured through a binary variable attached to the propensity to train rather than a continuous or discrete variable associated with training intensity.

Because of its nature, on-the-job training can be also associated with the presence of job-related practices, such as quality circles, job rotation and team working. Accordingly, the effect on on-thejob training on productivity also depends on its complementary relationships among different jobrelated practices in favouring the process of skill development. Together with on-the-job training, these practices mainly contribute to develop idiosyncratic technical skills. It has been shown, indeed, that there are positive complementarities between different workforce development practices in determining the overall effect of personnel policies, and that it is the overall bundle of practices that is important rather than the adoption of individual practices (Milgrom and Roberts, 1995; MacDuffie, 1995; Ichniowski et al, 1997).

\section{The relationship between training and flexibility}

By keeping this in mind, we can further investigate the relationship between training and flexibility. If we simply refer to Atkinson's notion of flexibility, one can be tempted to claim the existence of a trade-off between numerical flexibility and employers' propensity to training; i.e.: the higher the employees' attachment to the workplace the higher the employer's propensity to provide training for her employees. This trade-off underpins the relationship between numerical and functional flexibility: the lower the degree of numerical flexibility the greater the employer's propensity to provide training and, as a result, the greater the degree of functional flexibility. Functional flexibility requires an unspecified amount of training and can be fostered only when expected tenure of employees is quite high. Substantially, this was the institutionalist position in the 80s (Piore, 1986).

Atkinson's approach focuses only on the direct effects that the personnel practices directed to reinforcing flexibility have on workers. According to this approach, those workers who favour the strengthening of numerical flexibility (for instance, temps) do not provide functional flexibility, directly. The expected short-term attachment of these workers to the firm does not make it rewarding the provision of training for them. However, if one considers how the measures directed to reinforce flexibility interact with other personnel practices and/or firm's strategies, things can be different. In this case the focus is not only on the direct effects of the introduction of a single personnel practice on workers, but also on the interaction among different practices. Notably, while an intervention aimed at increasing numerical flexibility is expected to have a direct negative effect on the propensity to provide training to the employees directly involved in this measure, this 
measure can interact with other practices, favouring the provision of training to the employees as a whole ${ }^{9}$. Especially, if one considers a segmented internal labour market, where a contingent workforce coexists with a segment of employees with a long-term tenure, one can observe that an increase in numerical flexibility, reached through an increase in the incidence of temporary workers, can be consistent with an increase in the amount of training for the stable component of the workforce. In this way the two components of the workforce serve two distinct but complementary targets; the contingent segment provides numerical flexibility, whereas the stable tier of the workforce points to the enhancement of functional flexibility (or operational flexibility, using Volberda's terminology) through the acquisition of new skills. In this case the provision of training to the stable workforce can increase the cost of lay-offs and has to be balanced by an increase in the pool of contingent employees, in order to restore numerical flexibility.

In the case just outlined flexibility is reached by applying different strategies to different segments of the internal labour market. Yet, this is not the only scenario in which the furthering of functional flexibility occurs without hampering numerical flexibility. An employer can conceive to design job posts, so that these require a minimum amount of on-the-job training and a high degree of general training. If this is technologically feasible, general training substitutes for on-the-job training, and favours the advancement of functional flexibility. On the other hand, a minimum amount of investments in on-the-job training implies that these job positions can be assigned to workers with temporary contracts, which can be easily terminated ${ }^{10}$. Using Atkinson's terminology, one can claim that in this way functional flexibility along with numerical flexibility have been strengthened.

Finally, in the systemic approach to the analysis of the relationship between training and flexibility, the idea of complementarity plays a key role. Accordingly, as a further application of the relevance of this notion, we claim that complementarity among different job-related practices plays a pivotal role when one also wants to assess the quality of training. Similarly, variety in training contents can be conceived as an attempt to exploit complementarity relationships among different skills. The idea is that, under the assumption of complementarity, the higher the variety among training contents, the higher the potential use of skills developed through training. For this reason variety is an indicator of the relevance acknowledged to the implementation of training practices for the pursuit of competitiveness and can be considered as an indicator of the quality of training.

\footnotetext{
${ }^{9}$ With reference to the evolution of the role played by temporary work agencies Osterman, Burton (2006) claim “ [...] what is striking about these firms is the new roles they are playing. They have penetrated into a wide range of occupations, and they play an important role in many firms' recruiting and training strategies."

${ }^{10}$ This is not the only strategy suitable to reinforce both functional and numerical flexibility. To accomplish this end a firm could also decide to contract out some specific productive phases. This would be an alternative strategy to design a job post requiring high skills and poor investment in specific training.
} 


\section{Hypotheses}

Following our theoretical reasoning we proceed to formulate the hypotheses to be tested in the subsequent empirical analysis. Namely, we formulate four sets of hypotheses. Each of them consists of two different statements: the first statement is related to the standard economic approach, whereas the second statement derives from the systemic approach to the analysis of the firm and its training practices. However, it is important to underline that each statement does not rule out the other one.

First, we can expect a lower provision of off-the-job training in presence of non-standard workers. A higher job instability would lead to a shorter expected duration for the firm to recover training investments. Ceteris paribus, this would lead to a lower intensity of off-the-job training at firm level. Similarly, when considering the effect of a single intervention on numerical flexibility a trade-off between numerical flexibility and provision of training is expected to prevail.

\section{Hypothesis la}

The recourse to non-standard employment is negatively associated with off-the-job training intensity. (Human capital approach)

However, once taking into account the different dimensions of flexibility, and considering the firm as a cobweb of interconnected organisational arrangements, one can claim that training practices and the interventions to intensify the numerical flexibility are complementary and can reinforce each other.

\section{Hypothesis $1 b$}

Overall, off-the-job training intensity is positively associated with the presence of non-standard workers. (Flexibility approach)

Second, with reference to on-the-job training, if we consider a simple two-period model we can claim that the firm's propensity to provide on-the-job training depends on the time distribution of benefits accruing to the firm. If the firm manages to concentrate the benefits in the initial period, then the presence of non-standard workers is not likely to affect the employers' training decisions. Moreover, in cases where specific skills are characterised by a high rate of obsolescence, on-the-job training has to be provided to all workers regardless their attachment to the firm. 
The recourse to non-standard employment is not associated with the propensity to invest in on-thejob training (Human capital approach).

On the other hand, for the same reasons as those outlined for off-the-job training, one can assert that on-the-job training and numerical flexibility can be positively associated. This argument is reinforced if on-the-job training and off-the-job training are complementary. Moreover, as stated in paragraph 4, the employer can adopt a job design strategy aimed at minimising on-the-job training by substituting it with off-the-job training. Accordingly, the propensity to provide on-the-job training is expected to be negatively related to the presence of skilled workers. As outlined in the previous paragraph, in this case one can observe the strengthening of both functional and numerical flexibility at the same time.

\section{Hypothesis $2 b$}

The recourse to non-standard employment is positively associated with both the propensity to invest in on-the-job training and the presence of unskilled workers. (Flexibility approach)

Finally, when discussing the association between the quality of training, as measured in terms of variety of training contents and job-related practices, and the recourse to non-standard workers we can argue that the relationship between the quality of training and the presence of non-standard workers should be consistent with the results of the tests on Hypotheses 1 and 2 .

Hypothesis $3 a$

Training variety is negatively associated with the presence of non-standard contracts (Human Capital approach).

Hypothesis $3 b$

Training variety is positively associated with the presence of non-standard contracts (Flexibility approach).

Hypothesis $4 a$

The number of job-related practices is not associated with the presence of non-standard contracts (Human Capital approach). 
The number of job-related practices is positively associated with the presence of non-standard contracts. (Flexibility approach).

\section{Dataset and descriptive statistics}

For our empirical analysis we use data coming from the Survey on employee training in Italian firms performed by the National Institute of Statistics (ISTAT) in 2006 (reference year 2005), whose microdata have been released in 2012. These data allow us to distinguish off-the-job from on-the-job training, and to disentangle non-standard workforce between part-time, apprentices and temporary workforce. Data also provide different proxies of off-the-job training intensity: hours/days of training per employee, the number (or the proportion) of trained employees, training costs, and the content of training activity. The sample includes 15,470 firms employing more than 10 workers. Among them 6,439 (41.6\%) have provided some kind of off-the-job firm-sponsored training in 2005 (either internal or external), 2,533 (16.3\%) have provided on-the-job training activities (defined as a scheduled period of training, learning or practical experience to be carried out on the site or in the work situation), 2,128 (14.55\%) have provided both, meaning that $88.9 \%$ of on-the-job training firms also provides off-the-job training. Overall $43.45 \%$ of the firms report that they are engaged in some form of training activity, while the average number of employees of training firms is approximately twice larger than the overall mean.

Table 1 reports descriptive statistics on training incidence and intensity, and employment structure. Results are disaggregated according to the type of training and the presence of different type of flexible workers. The participation to training activities only involves a minority of the workforce of training firms: the share of workers that participate in training activities is $40.75 \%$ for off-the-job training and $29.03 \%$ for on-the-job-training. Off-the-job training intensity is low as well, on average. It amounts to 11.6 hours per employee per year, while training costs amount to 576 Euro per employee per year. In terms of contents, off-the-job training can be considered as mostly general, as expected. Almost the totality of off-the-job training firms develops some kind of general skills $(96 \%)$, while specific contents are provided by $62 \%$ of the sample. General training prevails in terms of intensity as well: on average, only 4.8 hours per employee can be considered as general, while general contents count for more than 9 hours per employee.

The survey also reports the diffusion of those job-related practices that are intrinsically related to training activities. These practices are represented by "quality circles", "self-learning" and "job rotation". Overall, the share of firms offering such practices is quite low: $7.81 \%$ for job rotation, $3.98 \%$ for self-learning, and $2.98 \%$ for quality circles. This percentage is actually poor and reflects the low propensity of Italian firms to activate innovative bundles of working practices in 
their plants. In relation to workforce characteristics, descriptive statistics show that most of the training firms employ non-standard workers. Overall, $68.81 \%$ and $59.91 \%$ of these firms include part-time and temporary workers in their workforce respectively. In approximately half of the cases they employ both types of workers, while $20.26 \%$ of the interviewed firms do not employ any of them. Few firms, however, offer training interventions that are specifically targeted for these types of workers (3.47\% for part-time workers and $7.81 \%$ for temporary workers). The recourse to apprenticeship contracts is scarcer: $41.72 \%$ of the firms employ at least one apprentice (this percentage raise to $42.30 \%$ in the subsample of training firms). Finally, we find that $36.72 \%$ of the training firms have at least one immigrant among their employees, while unskilled workers are present in $30.79 \%$ of the firms.

\section{$<$ Table 1a $>$}

$<$ Table $1 \mathrm{~b}>$

The existence of a correlation between off-the-job and on-the-job training is supported by the analysis of Pearson coefficients which show a substantial positive relationship between these two categories of training (0.42). Other correlation coefficients are reported in Table 2. As expected, the correlation between training variables is positive, although in the majority of the case the magnitude is poor. Some overlap only emerges between the propensity to provide on-the-job training and the presence of at least one job-related practice. Thus it is meaningful to jointly analyse on-the-job training and job-related practices when estimating their determinants.

$<$ Table 2>

The positive complementarity between the two types of training is confirmed by the results of a biprobit estimate that uses off-the-job and on-the-job propensity as dependent variables (Table 3). Artrho coefficient is highly positive and significant. Moreover, most characteristics influence offthe-job and on-the-job training in the same way (except for some industrial sector that only increases the probability to provide off-the-job training, such as finance and constructions). This is also true for the diffusion of job-related practices, which positively influences both types of training. On a reversed perspective, this result may also suggest that job-related practices require both types of training in order to be activated. 
$<$ Table 3>

\section{The econometric models}

In order to estimate the determinants of training, we estimate two econometric models where training propensity and intensity are seen as a function of the diffusion of non-standard contracts in the firm. Training propensity is a binary variable that takes the value one if the firm has provided training in 2005 and zero otherwise. To measure off-the-job training intensity our decision is to use the length of courses expressed in hours per year per employee. We exclude training costs because, if the aim is the comparability among different firms, training cost is an ambiguous variable. Each firm takes into account different components in assessing training costs, thus hampering the comparability among different firms. Training costs are instead considered as a control variable as they represent the price of training for the firms. On the other hand, to measure the diffusion of temporary and part-time workers, we use two dummy variables taking the value of unity if the firm employs either temporary or part-time contracts, respectively, and zero otherwise.

In specifying the econometric model for estimating the determinants of training intensity, we have to control for potential selection effects deriving from the observation of the dependent variable only for firms providing training in 2005. For this reason OLS estimate would suffer of a sample selection because training intensity is only observed if the firm decides to provide at least one training course. One of the standard estimation procedures for treating this selection problem is the two-step method proposed by Heckman (1979). However, this method is acceptable only if the dataset contain variables that can be used to identify the sample selection term. In absence of appropriate exclusion restrictions a multicollinearity problem is likely to arise (Puhani, 2000). Since the variables available in our dataset can not address this issue we decide to use a subsample OLS estimate for determining the effects of the presence of non-standard workers on off-the-job training intensity. Results are then controlled through a Tobit estimate by constructing a zero bounded dependent variable that takes the value of zero if the firm does not provide any training during the observed period.

The second model estimates the probability of investing in on-the-job training, conditioned on the provision of off-the-job training, as a function of the same covariates. Analogously to the previous model we face a selection bias arising from the censoring of the observations on the presence of flexible workers. However, in this case, the dataset contains two potential exclusion restrictions: working hours per employees and the amount of compulsory social contributions paid to the State for financing vocational training. These variables are likely to affect only the firms' decision to provide off-the-job training without influencing on-the-job training incidence. On-the- 
job training is carried on during working hours and does not enter in the computation of social contributions. This theoretical insight is supported by a test on the relationship of these variables with the outcome variable (off-the-job training hours per year per employee) that exclude their direct influence on the main equation. Accordingly, we use a Probit model with sample selection (heckprobit) where the selection equation is a Probit equation on the probability of providing offthe-job-training. Additionally, we control for selection in observables using propensity score matching technique (PSM) for three treatment variables: the presence of temporary, part-time and unskilled workers. In this way, after checking that the common support condition is satisfied across more than $95 \%$ of treatment and comparison groups, we create matched "treatment" and "control" samples being identical in every other observable respect ${ }^{11}$. In particular, when using the presence of unskilled workers as the treatment variable, the common support condition is properly satisfied for the entire range of the observations while some treated firms have lots of close neighbours and others only have one. Accordingly, in the analysis of the effects of the presence of unskilled workers we decide to use the kernel matching procedure in view of its capability to maximize precision without worsening bias, while nearest neighbours technique is used as a robustness check. If matching is sufficiently good, differences in the propensity to provide on-the-job training can be used as estimates of the effect of employing either non-standard or unskilled workers on this outcome variable. (Garrido et al., 2014).

Then we proceed to estimate the relationship between the presence of non-standard workers and the variety of training contents. In order to estimate this relationship we build a synthetic index of variety (ginicont) that measure the degree of variety of training contents provided by the firms in the sample ranging from 0 (equidistribution) to 1 (concentration). Once constructed we use this indicator as the dependent variable of a subsampled OLS regression that includes the same set of explanatory variables of the previous estimations. In this way we determine the effects of nonstandard contracts on the degree of variety of the contents provided to the workers through off-thejob training interventions.

Finally, in order we estimate the probability to activate a bundle of complementary job-related activities, we associate on-the-job training with job-related practices by counting the number of practices that are simultaneously reported by the firms in the sample. The dependent variable is discrete and takes non-negative values ranging from zero (no work-related practice) to five (all work-related practices). In order to choice the appropriate count data estimator we preliminary need to assess the degree of overdispersion and the excess of zeros. Given the low level of the variancemean ratio, and the non-rejection of the null hypothesis of equidispersion using the LM test

\footnotetext{
${ }^{11}$ Results of the distribution of propensity scores across treatment and comparison groups are available on request.
} 
suggested by Cameron, Trivedi (2013), the former issue does not impede the use of a Poisson regression. On the contrary, we need to allow that the function generating the zero observation (no work-related practices) differ from the one associated with positive observations and thus deal with the "excess zeros" problem. The zero-inflated model addresses this issue by supplementing the base model with a binary process, in our case a probit model, that explain the excess of probability of having zero work-related practices.

In all the models we introduce control variables related to several workplace characteristics at firm level that have been commonly found as determinants of training propensity and intensity: size, employment structure, innovation propensity, industry dummies ("other industries" is the benchmark), trade union recognition, and the organization of training activity. Employment structure includes the following variables measured as a ratio of total workers: women, young workers ( $<24$ years old), managers. Training organization includes the following dummy variables: the presence of a training department and a person in charge for training; the adoption of training evaluation procedures based on workers' satisfaction, learning achievements, and performance; the adoption of a training plan; the existence of a training budget; a formal role of trade unions in influencing firm's training investments and the presence of firm-level contract clauses dealing with training interventions. Rationale for this selection is supported by both theoretical and empirical literature. Large firms may be better able to bear the risk associated with investments in general training (Goux, Maurin, 2000) while achieving economies of scale in the provision of specific training (O'Connell, 2007), and are more likely to report the presence of temporary and/or part-time worker in their workforce. Gender and age may affect the employer's willingness to train as well as training intensity. In particular women are less-likely be offered formal on-the-job training than men (Evertsson, 2004), while older workers are less likely to be offered job-related training due to their lower expected payoff (Gelderblom and de Koning, 2006). On the contrary, the younger the worker, the higher the expected return from training, both for the firm and the individual. The propensity to innovate is also expected to be positively related to training and other job-related practices (Gashi et al., 2010). In line with our theoretical framework, a positive relationship between the adoption of job-related practices and training intensity is assumed to be in place (Whitfield, 2000). Finally, the role of trade unions and firm-level contract clauses in the training decision-making process are also expected to be associated with increased training intensity (Green et al., 1999; Groot, 1999) as well as all variables concerning training organization and evaluation procedures (O’Connell, 2007).

\section{Results}


In this section we discuss our empirical evidence by separately testing the hypotheses worked out in the previous paragraph.

\section{Off-the-job training}

In tables 4 and 5 one can observe that the diffusion of non-standard employment has divergent effects on off-the-job training according to the type of contract. In all specifications, the presence of part-time contracts negatively affects the intensity of off-the-job training financed by the employer. In particular the presence of part-time workers lowers training intensity by $9 \%$ on average. This percentage is higher if we control for the adoption of job-related practices (second specification), which are usually deemed as complementary to off-the-job training, and positively associated with training investments. On the contrary, controlling for variables related to training organization and incentive contracts contributes to a drop of the penalty, meaning that firms employing part-time workers are also characterized by a less formalized organization of training activities. This result is robust to the inclusion of a wide set of controls and substantially confirmed by Tobit estimates, although the magnitude and the significance of the coefficients are slightly lower using this second technique. Overall, this evidence confirms the Human capital hypothesis (Hypothesis 1a); the recourse to part-time contracts is detrimental for off-the-job training intensity in Italy.

Conversely the effect of the presence of temporary workers on training investments is positive at a first glance. Firms employing temporary workers provide on average 7\% less training than those firms that do not employ this type of workers. However, the level of significance is acceptable only in the first specification, and is not significant at all according to Tobit estimates. Therefore, there is no substantial evidence that the presence of temporary contracts induce employers to reduce the intensity of off-the-job training. Basically, neither the hypothesis 1a nor the hypothesis $1 \mathrm{~b}$ is supported by strong empirical evidence. This might suggest that the two effects at the basis of the two hypotheses coexist and cancel each other out.

Concerning control variables, the second and third specifications show the effects of job-related practices, organization of training activities, and internal industrial relations on off-the-job training intensity. Job-related practices have a positive impact, which is in line with the hypothesis that there is strong complementarity between these organizational practices and off-the-job training investments. This is consistent with the idea that the human capital approach is not sufficient to explain firms' investments in general training. The organization of the office in charge for training activity (presence of a plan and a budget) also has positive effects on training intensity, while the evaluation of training activity is found to be positive only if the outcome indicators refers to worker's satisfaction and learning achievements. The last set of variables concern the explicit role 
of contract clauses and trade unions in stimulating off-the-job training. Their effect is not significant or slightly negative, respectively, and reflects the union resistance to the introduction of technological and organizational innovations that may reduce firm's labour demand, at least in the short run.

$<$ Table 4>

$<$ Table 5>

\section{On-the-job training}

Different results emerge from the estimate of the probability to provide on-the-job training adjusted for sample selection bias (Table 6). In all specifications the presence of part-time or temporary workers does not significantly affect the willingness to provide on-the-job-training. This is confirmed by the non-significant effect (ATT) of these variables when they are used as treatment variables in a PSM estimate using the same covariates of the first specification ${ }^{12}$ (Table 7). This is in line with a scenario in which the firm manages to concentrate the benefits in the initial period (Hypothesis 2a).

Results also partially supports the hypothesis $2 \mathrm{~b}$. The coefficient related to unskilled workers is positive and significant in the first specification. On average an increase of the presence of unskilled workers increases the probability to train by $4 \%$. This evidence is compatible with the double nature of on-the-job training, which, on the one hand, plays a relevant role in the process of skill formation for low-skilled workers and, on the other hand, simply facilitates the match between job posts and highly skilled workers. This result is supported by the PSM estimate using the presence of unskilled contracts as the treatment variable (Table 7). The ATT coefficient is very similar to those presented before and even more significant. Accordingly, PSM confirms a positive and significant effect of employing unskilled workers on the propensity to provide on-the-job training. To assess the quality of the matching, Table 8 presents the differences between the mean values of a subset of the covariates which are used to match the treatment and control groups. Overall, our treatment and comparisons appear to be rather similar after the matching, with no significant statistical differences in the means of the reported values. The statistical results are alike when we repeat the estimates using the nearest neighbour procedure.

\footnotetext{
12 Although the balancing for individual covariates across this two groups is not always fulfilled, the imbalance for the covariate is always limited to one block of propensity scores out of five. Detailed results are available on request.
} 
Differences with off-the-job training also emerge from industrial dummies which reflect the different weight of specific skills attached to the job posts created in each industry. Notably, financial sector has a negative impact on training propensity, thus showing an opposite sign with respect to off-the-job training. This is not surprising in the light of the characteristic of the demand for skills in this industry, which is basically oriented towards soft and transversal skills. Finally, the size effect is positive and higher than the one reported in the off-the-job selection equation, and suggests the existence of greater dimensional threshold attached to on-the-job training because of the higher fixed costs that they entail. Finally, when introducing the role of firm-level bargaining process and trade unions, we find that the presence of contract clauses dealing with formal training negatively affects the propensity to train, while and the involvement of trade unions is not significant. This may reflect that in presence of such contract clauses firms tend to concentrate their training efforts in off-the-job training, thus reducing the probability to activate on-the-job training programs.

$<$ Table 6>

$<$ Table 7>

$<$ Table 8>

\section{Training variety}

Table 9 reports the results on the relationship between training variety and the presence of nonstandard contracts, which are partially in line with our hypotheses. Actually, temporary workers positively affects the provision of differentiated contents, whereas part-time does not influence the variety of off-the-job training practices, as the sign of the coefficient is negative but statistically non-significant. This seems to confirm the different impact that these two distinct personnel practices have on training policies. Conclusively, one can state that the hypothesis $3 \mathrm{~b}$ is partially confirmed and that training variety is positively associated with the use of temporary labour contracts, but it is not affected by the presence of part-time.

$<$ Table 9>

\section{Job-related practices}


Finally, we introduce a further variable (agg_jbp) that counts the number of job-related practices activated by the firms in the sample and proceed to estimate the impact of employment characteristics on this variable through a zero-inflated Poisson regression as described in Section 5 (Table 10). Results show that the number of job-related practices increase by $13 \%$ in presence of part-time workers. This is in line with the prediction that those activities generating a positive return in the short term are not penalized by the presence of flexible workers. Conversely, temporary contracts are not significant at all. Accordingly, the coefficients calculated for part-time are consistent with the hypothesis $4 \mathrm{~b}$, whereas as far as the presence of temporary workers is concerned the evidence shows that we cannot reject the hypothesis $4 \mathrm{a}$, as the coefficients are not significantly different from 0. Quite interestingly, we find that the variety of job-related practices is positively associated to the presence of unskilled workers. If one considers that these practices can also be used to provide informal training, this result can also be viewed as a further confirm of the existence of a positive association between the use of unskilled workers and specific training.

\section{$<$ Table 10>}

\section{Conclusions}

This paper explores the relationship between the presence of non-standard workers and training investments in Italian firms. Italy has been facing a productivity slowdown during the last decade and it is therefore important to analyse the different determinants of firm's financed process of human capital accumulation. Non-standard employment is an issue in this respect, as the presence of flexible workers may affect training incidence, intensity, and quality. This issue has been addressed, among the others, by the human capital literature and the strategic management approach. Moreover, this effect may differ according to the type of training that is provided by the employer. Accordingly, by separately referring to off-the-job training, on-the-job training and jobrelated practices, we look at the relationship between the presence of non-standard contracts and training investments under these two different theoretical perspectives.

Our cross-sectional database on workplace training in Italian firms allows us to explore these issues. Specifically, the availability of several measures of training activity allows us to distinguish the different components of the relationship between the type of contract held by workers and the amount of training provided in the workplace. Thus we present econometric results for both on-thejob and off-the-job training by using several outcome variables: firms' propensity to train, training intensity, training variety, the simultaneous recourse to job-related practices. For each econometric model we report results using different specifications. In our broader specification we consider (in 
addition to "non-standard contracts" indicator) a wide set of controls including industry, size, workforce composition, and training organization.

The main empirical findings show different results according to the type of non-standard contract and training. With reference to the presence of part-time workers the evidence supports our basic hypotheses, namely the existence of a negative relationship between non-standard contracts and training at the workplace. The unambiguous negative association between part-time and training intensity seems to be consistent with the idea that part-time is mainly used to control numerical flexibility. Accordingly the rationale behind their hiring seems to be merely quantitative, whereas the argument that the recourse to this type of contracts should be accompanied by the provision of new skills to the stable tier of the workforce is not supported. On the contrary, results for temporary contracts are partially different. Their presence seems to correspond to a twofold function of fixedterm contracts in the pursuit of productivity enhancements. On the one hand, they are aimed at reinforcing the numerical flexibility of the firms. On the other hand, they can be seen as a tool for complementing the promotion of functional flexibility obtained through an increase of training interventions for the stable tier of the workforce. This role in developing a bundle of different skills is confirmed by the positive association of temporary employment with training variety. Thus, the recourse to temporary workers can be viewed as a tool a complementarity between different types of flexibility. This does not mean, however, that this category of workers would benefit of a higher amount of training.

With regard to on-the-job training, our basic result is twofold. First, non-standard contracts do not significantly influence firms' choice to provide on-the-job training to their workers in line with human capital theory. Second, on-the-job training is positively related to the presence of part-time workers when interacting with other job-related practices, while this is not the case for temporary employees. This evidence can reflect the decision to substitute off-the-job training with on-the-job training and job-related practices in presence of part-time workers in order to shorten the pay-back period of the investments in human capital development. Thus, the idea that the recourse to parttime employment is used to promote complementarity is not fully supported. Moreover, in the light of the negative relationship between part-time employment and off-the-job training intensity, the presence of part-time workers could inhibit the optimal combination between off-the-job and onthe-job training.

Finally, from the worker's perspective, training is more likely to exacerbate rather than mitigate existing labour market inequalities. In particular, for part-time workers, the substitution between different types of training can be harmful for his/her career path because the productivity differential attached to on-the-job training interventions can be only enjoyed within the firm. In 
parallel, employees' motivation to learn from training could be negatively affected as well. This accentuates the importance of the transition probability to a full-time contract with the same employer. Accordingly, if part-time contract is either voluntary or a "stepping stone" workers will benefit of the skills acquired thanks to the intervention, otherwise, if it is a "dead end", they will suffer a net loss from the participation in on-the-job training.

\section{References}

Acemoglu, D. (1997). Training and innovation in an imperfect labor market,' Review of Economic Studies, 64, 445-64.

Acemoglu, D., Pischke, J. S. (1999), Beyond Baker: Training in imperfect labour markets. Economic Journal, 109, F112-F142.

Addison J., Belfield C. R. (2004), Unions, training, and firm performance: evidence from the British Workplace Employee Relations Survey, IZA Discussion Paper No. 1264.

Albert C., Garcia-Serrano C., Hernanz V. (2005), Firm-provided training and temporary contracts Span. Econ. Rev., 7, 67-88.

Albert C., Garcia-Serrano C., Hernanz V. (2010), On-the-job training in Europe: determinants and wage returns, International Labour Review, 149, 315-341.

Almeida-Santos F., Mumford K. (2004), Employee Training in Australia: Evidence from AWIRS, The Economic Record, 80, S53-S64.

Argyris, C., Schön, D.A. (1978), Organizational Learning: a Theory of Action Perspective, Reading, Mass., Addison-Wesley.

Arulampalam, W., Booth, A. L. (1998), Training and labour market flexibility. Is there a trade-off?, British Journal of Industrial Relations, 36, 521-536.

Arulampalam, W.; Booth, A. L.; Bryan, M. L. (2003), Training in Europe, IZA Discussion paper series, No. 933.

Atkinson J. (1985), Flexibility, uncertainty and manpower management, Institute of Manpower Studies, report n. 89.

Barrett., A. O’Connell, P. J. (2001), Does training generally work? The return of in-company training, Industrial and Labour Relation Review, 54, 623-655.

Barrett, G.F., Doiron, D.J. (2001). Working Part-Time by Choice OR By Constraint, Canadian Journal of Economics, 34, 1042-65.

Bassanini, A., Booth, A., Brunello, G., De Paola, M., Leuven, E. (2005), Workplace training in Europe, IZA Discussion Paper N. 1640.

Becker G. (1964), Human Capital, New York, Columbia University Press. 
Beckman M. (2002), Firm-sponsored apprenticeship training in Germany: empirical evidence from establishment data, Labour, 16(2), 287-310.

Bentolilla, S., Dolado, J., Jimeno J. (2008), Two-tier Employment Protection Reforms: The Spanish Experience, Journal for International Comparisons, 6 , 49-56.

Berton, F., Richiardi, M., Sacchi, S. (2009). Flex-insecurity. Perché in Italia la flessibilità diventa precarietà, Bologna, Il Mulino.

Boheim R., Booth, A. (2004) Trade Union Presence and Employer-Provided Training in Great Britain, Industrial Relations, 43, 520-545.

Booth, A., Bryan, M. (2002), Who pays for general training? New evidence for British men and women, IZA Discussion Paper No. 486.

Booth A. L., van Ours J. C. (2008), Job Satisfaction and Family Happiness: The Part-Time Work Puzzle, The Economic Journal, 118, F77-F99.

Brunello G. (2001), On the Complementarity between Education and Training in Europe, IZA Discussion Paper No. 309.

Cabrales A., Dolado J.J., Mora R. (2014), Dual labour markets and (lack of) on-the-Job Training: PIAAC evidence from Spain and other EU countries, IZA Discussion Paper No. 8649.

Cameron C.A., Trivedi P.K. (2013), Regression Analysis of Count Data, New York, Cambridge University Press.

Chang, C., Whang, Y. (1996), Human capital investment under asymmetric information. The pigouvian conjecture revisited, Journal of Labor Economics, 14, 505-519.

Connolly S., Gregory M. (2009), The part-time pay penalty: earnings trajectories of British Women, Oxford Economic Papers, 61 (suppl 1), i76-i97.

Dearden L., Reed H., Van Reenen J. (2006), The Impact of Training on Productivity and Wages: Evidence from British Panel Data, Oxford Bullettin of Economics and Statistics, 68, 397-421.

Dolado, J. J., Garcia-Serrano C., Jimeno J. F. (2002), Drawing Lessons From The Boom Of Temporary Jobs In Spain, The Economic Journal, 112, 270-295.

Dolado, J. J., Stucchi, R. M. (2008) Temporary workers and firms' productivity: Evidence from the Spanish manufacturing sector. CEPR Discussion Paper No. 7055.

Dustman, C., Schonberg, U. (2012), What Makes Firm-Based Apprenticeships Work? The Role of Commitment to Training Provision, American Economic Journal: Applied Economic, 4, 36-61.

European Commission (2010), Employment in Europe 2010. Luxembourg: Publications Office of the European Union.

Evertsson M. (2004), Formal on-the-job training. A gender-typed experience and wage-related advantage, European Sociological Review, 20, 79-94. 
Fernández-Kranz D., Rodríguez-Planas N. (2011) The part-time pay penalty in a segmented labor market, Labour Economics, 18, 591-606.

Fouarge, D., Schils, T., de Grip, A. (2013), Why do low-educated workers invest less in further training? Applied Economics, 45(18): 2587-2601.

Forrier A., Sels L. (2003). Temporary employment and employability: training opportunities and efforts of temporary and permanent employees in Belgium, Work Employment and Society, 17(4), 641-666.

Garrido M. M, Kelley A. S., Paris J., Roza K., Meier D. E., Morrison R. S., Aldridge D. (2014) Methods for constructing and assessing propensity scores, HSR: Health Services Research, 49, 1701-1720.

Gashi A., Pugh G., Adnett N. (2010), Technological change and employer-provided training: evidence from UK workplaces, International Journal of Manpower, 31, 426-448.

Gelderblom A. and de Koning J. (2006), ICT and older workers: no unwrinkled relationship, International Journal of Manpower, 27, 467-490.

Goux D. Maurin E. (2000) Returns to firm-provided training: evidence from French worker-firm matched data, Labour Economics, 7, 1-19.

Green F., Machin S., Wilkinson D. (1999), Trade Unions and Training Practices in British Workplaces, Industrial and Labor Relations Review, 52, 179-195.

Groot, W. (1999). Enterprise related training: a survey. In F. van Wieringen, \& G. Attwell (Eds.), Vocational and Adult Education in Europe, Dordrecht, Kluwer Academic Publishers, 357-373.

Heckman J.J. (1979) Sample Selection Bias as a Specification Error, Econometrica, 47(1), 153-161.

Katz, E., Ziderman, A. (1990). Investment in General Training: The Role of Information and Labour Mobility. The Economic Journal, 100, 1147-1158.

Kessler, A.S., Lulfesmann, C. (2006). The theory of human capital revised: on the interaction of general and specific investments, The Economic Journal, 116, 903-923.

Ichniowski, C., Shaw, K. \& Prennushi, G. (1997) The effects of human resource management practices on productivity: A study of steel finishing lines, American Economic Review, 87, 291313.

Leuven E., Oosterbeek H. (1999), Demand and supply of work-related training: evidence from four countries, in Polachek S. W. and Robst J. (eds.), Research in Labor Economics, 18, 303-30.

Manning and Petrongolo (2008), The part-time pay penalty for women in Britain, Economic Journal, 118, F218-F51. 
MacDuffie, J. P. (1995), Human resource bundles and manufacturing performance: Organizational logic and flexible production systems in the world auto industry, Industrial and Labor Relations Review, 48, 197-221.

Milgrom P., and Roberts J. (1995), Complementarities and Fit: Strategy. Structure. and Organizational Change in Manufacturing, Journal of Accounting and Economics, 19, 179-208.

Mumford, K., Smith, P., 2007. The gender earnings gap in Britain: including the workplace. Manchester School 75, 653-672

Nordman C. and Hayward G. (2006) Returns to On-the-Job Training: Do Skill Usage, Tasks and Workstation Matter? SKOPE Research Paper 63 January 2006.

Evidence from British Workers

O'Connell, P. (2007). Who generally trains? The effects of personal and workplace characteristics on training at work, in Lassnigg et al., (eds.), Lifelong Learning: Building Bridges through Transitional Labour Markets. Apeldoorn, Belgium: Het Spinhuis.

O'Connell, P., Byrne D. (2012), The Determinants and Effects of Training at Work: Bringing the Workplace Back in, European Sociological Review, 28, 3, 283-300.

OECD (2002), OECD Employment Outlook, Paris, OECD.

OECD (2003), OECD Employment Outlook, Paris, OECD.

OECD (2004), OECD Employment Outlook, Paris, OECD.

Oosterbeek, H. (1996) A decomposition of training probabilities, Applied Economics, 28, 799-805.

Oosterbeek, H. (1998), Unravelling supply and demand factors in work-related training, Oxford Economic Papers, 50, 266-283.

Osterman P., Burton D. (2006), Ports and Ladders. The nature and relevance of internal labor market in a changing world, in Ackroyd S., Batt R., Thompson P., Tolbert P. (2006), The Oxford Handbook of Work and Organisation, Oxford, Oxford University Press.

Piore M.J. (1986), Perspectives in labor market flexibility, Industrial Relations, vol. 25, n. 2, 146166.

Puhani P. A. (2000) The Heckman correction for sample selection and its critique, Journal of Economic Surveys, 14, 53-67.

Sauermann J. (2006), Who invests in training if contracts are temporary? Empirical evidence for Germany using selection correction, IWH-Discussion Papers N. 14-06.

Volberda H. W. (1998), Building the Flexible Firm: How to Remain Competitive, Oxford, Oxford University Press.

Whitfield K. (2000), High-performance workplaces, training, and the distribution of skills, Industrial Relations, 39, 1-25. 
Table 1a - Descriptive statistics: quantitative variables

\begin{tabular}{|c|c|c|c|}
\hline Variable & Obs & Mean & Std. Dev. \\
\hline \multicolumn{4}{|l|}{ Employment structure } \\
\hline Number of employees & 15,470 & 135.9729 & 85.4404 \\
\hline Number of employees (training firms) & 6,721 & 262.239 & 1280.129 \\
\hline Proportion of males & 15,470 & 0.7104 & 0.2621 \\
\hline Proportion of males (training firms) & 6,721 & 0.7136 & 0.2385 \\
\hline Proportion of young workers & 15,470 & 0.0631 & 0.0984 \\
\hline Proportion of young workers (training firms) & 6,721 & 0.0605 & 0.0901 \\
\hline Proportion of old workers & 15,470 & 0.0747 & 0.0890 \\
\hline Proportion of old workers (training firms) & 6,721 & 0.0705 & 0.0799 \\
\hline Number of apprentices & 15,470 & 2.7828 & 22.5003 \\
\hline Number of apprentices (training firms) & 6,721 & 4.2757 & 31.6968 \\
\hline \multicolumn{4}{|l|}{ Quantity of labour used in the production process } \\
\hline Yearly working hours per employee & 15,470 & 1,592 & 312.7367 \\
\hline Yearly working hours per employee (training firms) & 6,721 & 1,612 & 286.5265 \\
\hline \multicolumn{4}{|l|}{ Labour costs } \\
\hline Labour cost per employee $(€)$ & 15,470 & 31,391 & 14,325 \\
\hline Labour cost per employee $(€)$ (training firms) & 6,721 & 36,544 & 16,318 \\
\hline Labour costs per hour $(€)$ & 15,470 & 19.980 & 9.2432 \\
\hline Labour costs per hour $(€)$ (training firms) & 6,721 & 23.027 & 10.7356 \\
\hline \multicolumn{4}{|l|}{ Training } \\
\hline Off-the-job training (hours per employee) & 5,986 & 11.667 & 17.6437 \\
\hline Off-the-job general training (hours per employee) & 5,747 & 9.046 & 14.5621 \\
\hline Off-the-job specific training (hours per employee) & 3,715 & 4.806 & 9.6441 \\
\hline External off-the-job training (hours per employee) & 5,239 & 7.261 & 12.4184 \\
\hline Internal off-the-job training (hours per employee) & 3,486 & 9.121 & 15.7799 \\
\hline Off-the-job training cost per employee $(€)$ & 5,986 & 576.918 & 880.6824 \\
\hline Off-the-job training direct cost per employee $(€)$ & 5,986 & 276.4628 & 492.4264 \\
\hline Off-the-job training opportunity cost per employee $(€)$ & 5,986 & 300.4551 & 504.6698 \\
\hline Off-the-job participation rate & 6,439 & $40.75 \%$ & 0.3661 \\
\hline On-the-job participation rate & 2,533 & $29.03 \%$ & 0.2862 \\
\hline
\end{tabular}


Table1b- Descriptive statistics: binary variables

\begin{tabular}{lcc}
\hline Variable & $\begin{array}{c}\text { Absolute } \\
\text { frequencies }\end{array}$ & Percentage \\
\hline Training propensity & & \\
Off-the-job training (including external conferences) & 6,439 & 41.62 \\
On-the-job training & 2,533 & 16.37 \\
At least one type of training & 6,721 & 43.45 \\
Both types of training & 2,251 & 14.55 \\
Type of Workers (only firms providing off-the-job training) & & \\
Presence of immigrants & 2,177 & 36.37 \\
Dedicated training for immigrants & 94 & 4.32 \\
Presence of unskilled workers & 1,843 & 30.79 \\
Dedicated training for unskilled workers & 237 & 12.86 \\
Presence of temporary workers & 3,586 & 59.91 \\
Dedicated training for temporary workers & 280 & 7.81 \\
Presence of part-time workers & 4,119 & 68.81 \\
Dedicated training for part-time workers & 143 & 3.47 \\
Organization & & \\
Training department & 2,619 & 38.21 \\
Training responsible & 4,258 & 62.12 \\
Training plan & 3,786 & 55.23 \\
Training budget & 2,728 & 39.80 \\
Contract clauses related to the participation to training activities & 1,865 & 27.21 \\
Trade unions' involvement in training provision & 2,120 & 30.93 \\
Evaluation of training effectiveness (firms that always or almost & & \\
always adopt it) & & \\
Trainees' satisfaction & 4.324 & 63.08 \\
Learning achievements & 1,974 & 28.80 \\
Workers' performance & 3,553 & 51.84 \\
Organisational performance & 2,007 & 29.29 \\
Job-related practices & & 7.91 \\
Job rotation & 1,224 & 2.98 \\
Quality circles & 461 & 3.98 \\
\hline Self-learning & 616 &
\end{tabular}


Table 2- Pairwise correlations

\begin{tabular}{|c|c|c|c|c|c|c|c|c|}
\hline Variables & empl & part-time & temp & unskilled & $\begin{array}{c}\text { off_- } \\
\text { hrs }\end{array}$ & $\begin{array}{l}\text { off__ } \\
\text { part }\end{array}$ & $\begin{array}{c}\text { on_- } \\
\text { propens }\end{array}$ & $\begin{array}{l}\text { job- } \\
\text { related } \\
\text { practices }\end{array}$ \\
\hline empl & 1.00 & & & & & & & \\
\hline part-time & 0.10 & 1.00 & & & & & & \\
\hline temp & 0.11 & 0.34 & 1.00 & & & & & \\
\hline unskilled & 0.10 & 0.20 & 0.28 & 1.00 & & & & \\
\hline off-hours & 0.83 & 0.08 & 0.08 & 0.07 & 1.00 & & & \\
\hline off_part & 0.03 & 0.08 & 0.01 & -0.04 & 0.09 & 1.00 & & \\
\hline on_propens & 0.09 & -0.01 & 0.11 & 0.10 & 0.08 & 0.15 & 1.00 & \\
\hline $\begin{array}{l}\text { job-related } \\
\text { practices }\end{array}$ & 0.14 & 0.16 & 0.15 & 0.13 & 0.13 & 0.30 & 0.71 & 1.00 \\
\hline
\end{tabular}

Table 3 - Bivariate probit estimate on the probability of providing training

\begin{tabular}{|c|c|c|}
\hline & On-the-job training & Off-the-job training \\
\hline \multirow[t]{2}{*}{ size } & $0.314^{* * *}$ & $0.520 * * *$ \\
\hline & $(-0.018)$ & -0.019 \\
\hline \multirow[t]{2}{*}{ working hours } & 0.000 & $-0.0001 * * *$ \\
\hline & $(0.000)$ & $(0.000)$ \\
\hline \multirow[t]{2}{*}{ labour cost/hour (log) } & $0.326 * * *$ & $0.712 * * *$ \\
\hline & $(-0.039)$ & $(-0.034)$ \\
\hline \multirow[t]{2}{*}{ females } & $-0.249 * * *$ & $-0.173 * *$ \\
\hline & $(-0.067)$ & $(-0.053)$ \\
\hline \multirow{2}{*}{ age $>55$} & $0.397 * *$ & $0.308 * *$ \\
\hline & $(-0.136)$ & $(-0.118)$ \\
\hline \multirow[t]{2}{*}{ age $<25$} & $-0.652 * * *$ & $-0.410 * *$ \\
\hline & $(-0.178)$ & $(-0.131)$ \\
\hline \multirow[t]{2}{*}{ innovativeness } & $0.326 * * *$ & $0.321 * * *$ \\
\hline & $(-0.030)$ & $(-0.027)$ \\
\hline \multirow[t]{2}{*}{ job rotation } & $1.377 * * *$ & $0.898 * * *$ \\
\hline & $(-0.043)$ & $(-0.049)$ \\
\hline \multirow[t]{2}{*}{ quality circles } & $0.797 * * *$ & $1.068 * * *$ \\
\hline & $(-0.073)$ & $(-0.104)$ \\
\hline \multirow[t]{2}{*}{ self-learning } & $0.702 * * *$ & $1.2901 * * *$ \\
\hline & $(-0.067)$ & $(-0.113)$ \\
\hline \multirow[t]{2}{*}{ _cons } & $-5.165 * * *$ & $-8.522 * * *$ \\
\hline & $(-0.384)$ & $(-0.332)$ \\
\hline \multirow[t]{2}{*}{ athrho } & & $0.690 * * *$ \\
\hline & & $(-0.022)$ \\
\hline Industrial dummies & Yes & Yes \\
\hline $\mathrm{N}$ & & 15470 \\
\hline chi2 & & 4501.9378 \\
\hline
\end{tabular}


Table 4 Determinants of off-the job training intensity (OLS estimates)

\begin{tabular}{|c|c|c|c|c|}
\hline & $\begin{array}{c}(1) \\
\text { Hours/employee } \\
(\log )\end{array}$ & $\begin{array}{c}(2) \\
\text { Hours/employee } \\
(\log )\end{array}$ & $\begin{array}{c}(3) \\
\text { Hours/employee } \\
(\log )\end{array}$ & $\begin{array}{c}(4) \\
\text { Hours/employee } \\
(\log )\end{array}$ \\
\hline part time & $\begin{array}{l}-0.142 * * \\
(0.056)\end{array}$ & $\begin{array}{l}-0.156^{* * *} \\
(0.055)\end{array}$ & $\begin{array}{l}-0.080 * * \\
(0.037)\end{array}$ & $\begin{array}{l}-0.091 * * \\
(0.036)\end{array}$ \\
\hline temporary workers & $\begin{array}{l}0.07 * \\
(0.052)\end{array}$ & $\begin{array}{l}0.063 \\
(0.051)\end{array}$ & $\begin{array}{l}0.038 \\
(0.035)\end{array}$ & $\begin{array}{l}0.033 \\
(0.034)\end{array}$ \\
\hline immigrants & $\begin{array}{l}-0.295 * * * \\
(0.056)\end{array}$ & $\begin{array}{l}-0.288 * * * \\
(0.055)\end{array}$ & $\begin{array}{l}-0.241 * * * \\
(0.034)\end{array}$ & $\begin{array}{l}-0.237 * * * \\
(0.034)\end{array}$ \\
\hline training cost/ hour $(\log )$ & $\begin{array}{l}-0.789 * * * \\
(0.054)\end{array}$ & $\begin{array}{l}-0.779 * * * \\
(0.053)\end{array}$ & $\begin{array}{l}-0.790 * * * \\
(0.035)\end{array}$ & $\begin{array}{l}-0.786 * * * \\
(0.035)\end{array}$ \\
\hline size & $\begin{array}{l}-0.110^{* * * *} \\
(0.031)\end{array}$ & $\begin{array}{l}-0.144 * * * \\
(0.031)\end{array}$ & $\begin{array}{l}-0.174 * * * \\
(0.020)\end{array}$ & $\begin{array}{l}-0.197 * * * \\
(0.020)\end{array}$ \\
\hline unskilled & $\begin{array}{l}0.153^{*} \\
(0.068)\end{array}$ & $\begin{array}{l}0.126 \\
(0.067)\end{array}$ & $\begin{array}{l}0.006 \\
(0.037)\end{array}$ & $\begin{array}{l}-0.014 \\
(0.036)\end{array}$ \\
\hline labour cost/hour (log) & $\begin{array}{l}0.029 * * * \\
(0.003)\end{array}$ & $\begin{array}{l}0.028 * * * \\
(0.003)\end{array}$ & $\begin{array}{l}0.027 * * * \\
(0.002)\end{array}$ & $\begin{array}{l}0.026 * * * \\
(0.002)\end{array}$ \\
\hline age $>55$ & $\begin{array}{l}-1.307 * * * \\
(0.283)\end{array}$ & $\begin{array}{l}-1.287 * * * \\
-0.279\end{array}$ & $\begin{array}{l}-0.895^{* * * *} \\
-0.184\end{array}$ & $\begin{array}{l}-0.882 * * * \\
-0.182\end{array}$ \\
\hline age $<25$ & $\begin{array}{l}0.104 \\
(0.257)\end{array}$ & $\begin{array}{l}0.09 \\
-0.254\end{array}$ & $\begin{array}{l}0.123 \\
-0.169\end{array}$ & $\begin{array}{l}0.119 \\
-0.169\end{array}$ \\
\hline females & $\begin{array}{l}-0.249 * \\
(0.124)\end{array}$ & $\begin{array}{l}-0.202 \\
-0.122\end{array}$ & $\begin{array}{l}-0.309 * * * \\
-0.081\end{array}$ & $\begin{array}{l}-0.289 * * * \\
-0.081\end{array}$ \\
\hline innovativeness & $\begin{array}{l}0.276 * * * \\
(0.055)\end{array}$ & $\begin{array}{l}0.210 * * * \\
(0.055)\end{array}$ & $\begin{array}{l}0.219 * * * \\
(0.033)\end{array}$ & $\begin{array}{l}0.175 * * * \\
(0.033)\end{array}$ \\
\hline job rotation & & $\begin{array}{l}0.280 * * * \\
(0.064)\end{array}$ & & $\begin{array}{l}0.194 * * * \\
-0.041\end{array}$ \\
\hline quality circles & & $\begin{array}{l}0.434 * * * \\
(-0.100)\end{array}$ & & $\begin{array}{l}0.232 * * * \\
-0.056\end{array}$ \\
\hline self learning & & $\begin{array}{l}0.632 * * * \\
(0.086)\end{array}$ & & $\begin{array}{l}0.529 * * * \\
-0.05\end{array}$ \\
\hline training plan & & & $\begin{array}{l}0.330 * * * \\
(0.037)\end{array}$ & $\begin{array}{l}0.311 * * * \\
(0.037)\end{array}$ \\
\hline training budget & & & $\begin{array}{l}0.360 * * * \\
(0.039)\end{array}$ & $\begin{array}{l}0.345 * * * \\
(0.039)\end{array}$ \\
\hline workers' satisfaction & & & $\begin{array}{l}0.047 * * \\
(0.016)\end{array}$ & $\begin{array}{l}0.039 * \\
(0.016)\end{array}$ \\
\hline learning achievements & & & $\begin{array}{l}0.076 * * * \\
(0.017)\end{array}$ & $\begin{array}{l}0.066 * * * \\
(0.016)\end{array}$ \\
\hline trainees' performance & & & $\begin{array}{l}0.015 \\
(0.016)\end{array}$ & $\begin{array}{l}0.012 \\
(0.016)\end{array}$ \\
\hline training clauses & & & $\begin{array}{l}-0.016 \\
(0.037)\end{array}$ & $\begin{array}{l}-0.019 \\
(0.036)\end{array}$ \\
\hline trade unions involvement & & & $\begin{array}{l}-0.078 * \\
(0.034)\end{array}$ & $\begin{array}{l}-0.083 * \\
(0.034)\end{array}$ \\
\hline _cons & $\begin{array}{l}4.559 * * * \\
(0.222)\end{array}$ & $\begin{array}{l}4.491 * * * \\
(0.219)\end{array}$ & $\begin{array}{l}4.183 * * * \\
(0.144)\end{array}$ & $\begin{array}{l}4.205 * * * \\
(0.142)\end{array}$ \\
\hline Industrial dummies & Yes & Yes & Yes & Yes \\
\hline $\begin{array}{l}\mathrm{N} \\
\mathrm{R} 2\end{array}$ & $\begin{array}{l}5986 \\
0.162\end{array}$ & $\begin{array}{l}5986 \\
0.188\end{array}$ & $\begin{array}{l}5986 \\
0.242\end{array}$ & $\begin{array}{l}5986 \\
0.261\end{array}$ \\
\hline
\end{tabular}

Standard errors in parentheses

${ }^{*} p<0.10,{ }^{* *} p<0.05,{ }^{* * *} p<0.01$ 
Table 5 Determinants of off-the job training intensity (Tobit estimates)

\begin{tabular}{|c|c|c|c|c|}
\hline & $\begin{array}{c}(1) \\
\text { Hours/employee } \\
(\log )\end{array}$ & $\begin{array}{c}(2) \\
\text { Hours/employee } \\
(\log )\end{array}$ & $\begin{array}{c}(3) \\
\text { Hours/employee } \\
(\log )\end{array}$ & $\begin{array}{c}(4) \\
\text { Hours/employee } \\
(\log )\end{array}$ \\
\hline \multirow[t]{2}{*}{ part time } & $-0.114^{*}$ & $-0.129 *$ & -0.105 & $-0.118^{*}$ \\
\hline & $(0.057)$ & $(0.055)$ & $(0.055)$ & $(0.054)$ \\
\hline \multirow[t]{2}{*}{ temporary workers } & 0.073 & 0.07 & 0.049 & 0.049 \\
\hline & $(0.052)$ & $(0.051)$ & $(0.049)$ & $(0.048)$ \\
\hline \multirow[t]{2}{*}{ immigrants } & $-0.279 * * *$ & $-0.272 * * *$ & $-0.246 * * *$ & $-0.240 * * *$ \\
\hline & $(0.055)$ & $(0.054)$ & $(0.051)$ & $(0.051)$ \\
\hline \multirow[t]{2}{*}{ training cost/ hour (log) } & $-0.790 * * *$ & $-0.781 * * *$ & $-0.801 * * *$ & $-0.794 * * *$ \\
\hline & $(0.053)$ & $(0.053)$ & $(0.052)$ & $(0.052)$ \\
\hline \multirow[t]{2}{*}{ size } & 0.059 & 0.052 & 0.035 & 0.03 \\
\hline & $(0.065)$ & $(0.064)$ & $(0.063)$ & $(0.062)$ \\
\hline \multirow[t]{2}{*}{ unskilled } & $0.161 *$ & $0.132 *$ & $0.138^{*}$ & 0.119 \\
\hline & $(0.067)$ & $(0.066)$ & $(0.062)$ & $(0.062)$ \\
\hline \multirow[t]{2}{*}{ labour cost/hour (log) } & $0.037 * * *$ & $0.037 * * *$ & $0.037 * * *$ & $0.037 * * *$ \\
\hline & $(0.004)$ & $(0.004)$ & $(0.003)$ & $(0.003)$ \\
\hline \multirow[t]{2}{*}{ age $>55$} & $-1.157 * * *$ & $-1.146 * * *$ & $-1.077 * * *$ & $-1.074 * * *$ \\
\hline & $(0.281)$ & $(0.277)$ & -0.277 & -0.275 \\
\hline \multirow[t]{2}{*}{ age $<25$} & 0.145 & 0.120 & 0.206 & 0.189 \\
\hline & $(0.263)$ & $(0.258)$ & -0.235 & -0.235 \\
\hline \multirow[t]{2}{*}{ females } & -0.154 & -0.113 & -0.144 & -0.113 \\
\hline & $(0.128)$ & $(0.126)$ & $(0.119)$ & $(0.119)$ \\
\hline \multirow[t]{2}{*}{ innovativeness } & $0.283 * * *$ & $0.218 * * *$ & $0.234 * * *$ & $0.189 * * *$ \\
\hline & $(0.055)$ & $(0.055)$ & $(0.051)$ & $(0.051)$ \\
\hline \multirow[t]{2}{*}{ job rotation } & & $0.291 * * *$ & & $0.206 * * *$ \\
\hline & & $(0.064)$ & & $(0.062)$ \\
\hline \multirow[t]{2}{*}{ quality circles } & & $0.432 * * *$ & & $0.326 * * *$ \\
\hline & & $(0.098)$ & & $(0.094)$ \\
\hline \multirow[t]{2}{*}{ self learning } & & $0.613 * * *$ & & $0.523 * * *$ \\
\hline & & $(0.086)$ & & $(0.082)$ \\
\hline \multirow[t]{2}{*}{ training plan } & & & $0.363 * * *$ & $0.333 * * *$ \\
\hline & & & $(0.055)$ & $(0.055)$ \\
\hline \multirow[t]{2}{*}{ training budget } & & & $0.274 * * *$ & $0.269 * * *$ \\
\hline & & & $(0.061)$ & $(0.060)$ \\
\hline \multirow[t]{2}{*}{ workers' satisfaction } & & & 0.021 & 0.019 \\
\hline & & & $(0.023)$ & $(0.023)$ \\
\hline \multirow[t]{2}{*}{ learning achievements } & & & $0.064^{*}$ & $0.056^{*}$ \\
\hline & & & $(0.025)$ & $(0.025)$ \\
\hline \multirow[t]{2}{*}{ trainees' performance } & & & $0.056^{*}$ & $0.046^{*}$ \\
\hline & & & $(0.024)$ & $(0.024)$ \\
\hline \multirow[t]{2}{*}{ training clauses } & & & $-0.145^{*}$ & $-0.143^{*}$ \\
\hline & & & $(0.058)$ & $(0.057)$ \\
\hline \multirow[t]{2}{*}{ trade unions involvement } & & & -0.103 & $-0.107 *$ \\
\hline & & & $(0.054)$ & $(0.053)$ \\
\hline \multirow[t]{2}{*}{ _cons } & $4.278 * * *$ & $4.315 * * *$ & $4.234 * * *$ & $4.283 * * *$ \\
\hline & $(0.311)$ & $(0.309)$ & $(0.307)$ & $(0.306)$ \\
\hline sigma & $1.170 * * *$ & $1.152 * * *$ & $1.127 * * *$ & $1.116 * * *$ \\
\hline & $(0.017)$ & $(0.017)$ & $(0.016)$ & $(0.016)$ \\
\hline Industrial dummies & Yes & Yes & Yes & Yes \\
\hline $\mathrm{N}$ & 5914 & 5914 & 5914 & 5914 \\
\hline Pseudo-R2 & 0.0429 & 0.0522 & 0.0641 & 0.0703 \\
\hline
\end{tabular}

Standard errors in parentheses

${ }^{*} p<0.10,{ }^{* * *} p<0.05,{ }^{* * *} p<0.01$ 
Table 6- Propensity to provide on-the-job training (HeckProbit estimates - marginal effects)

\begin{tabular}{|c|c|c|c|c|}
\hline & ontrain & ontrain & ontrain & ontrain \\
\hline \multirow[t]{2}{*}{ part time } & 0.0128 & 0.0065 & 0.0167 & 0.0085 \\
\hline & $(0.0245)$ & $(0.0245)$ & $(0.0244)$ & $(0.0245)$ \\
\hline \multirow[t]{2}{*}{ temporary workers } & 0.0201 & 0.0199 & 0.0076 & 0.0104 \\
\hline & $(0.0235)$ & $(0.0237)$ & $(0.0233)$ & $(0.0232)$ \\
\hline \multirow[t]{2}{*}{ immigrants } & 0.0215 & 0.0196 & 0.0255 & 0.0234 \\
\hline & $(0.0242)$ & $(0.0244)$ & $(0.0237)$ & $(0.0237)$ \\
\hline \multirow[t]{2}{*}{ training cost/ hour $(\log )$} & -0.0362 & -0.0290 & -0.0357 & -0.0300 \\
\hline & $(0.0230)$ & $(0.0233)$ & $(0.0228)$ & $(0.0230)$ \\
\hline \multirow[t]{2}{*}{ size } & $0.0418 * *$ & $0.0397 *$ & 0.0304 & 0.0324 \\
\hline & $(0.0512)$ & $(0.0203)$ & $(0.0197)$ & $(0.0197)$ \\
\hline \multirow[t]{2}{*}{ unskilled } & $0.0455^{*}$ & 0.0257 & 0.0367 & 0.0210 \\
\hline & $(0.0260)$ & $(0.0267)$ & $(0.0264)$ & $(0.0266)$ \\
\hline \multirow[t]{2}{*}{ labour cost/hour (log) } & -0.0006 & -0.0001 & 0.0003 & 0.0009 \\
\hline & $(0.0015)$ & $(0.0017)$ & $(0.0014)$ & $(0.0014)$ \\
\hline \multirow[t]{2}{*}{ workers aged >55 } & -0.2312 & -0.2146 & -0.2283 & -0.2056 \\
\hline & $(0.1404)$ & $(0.1431)$ & $(0.1450)$ & $(0.1455)$ \\
\hline \multirow[t]{2}{*}{ workers aged <25 } & -0.0741 & -0.1188 & -0.0554 & -0.0991 \\
\hline & $(0.3132)$ & $(0.1187)$ & $(0.1191)$ & $(0.1150)$ \\
\hline \multirow[t]{2}{*}{ females } & $-0.1732 * * *$ & $-0.1761 * * *$ & $-0.1714 * * *$ & $-0.1742 * * *$ \\
\hline & $(0.0589)$ & $(0.0566)$ & $(0.0574)$ & $(0.0555)$ \\
\hline \multirow[t]{2}{*}{ innovativeness } & $0.0990 * * *$ & $0.0729 * * *$ & $0.0871 * * *$ & $0.0669 * * *$ \\
\hline & $(0.0286)$ & $(0.0276)$ & $(0.0260)$ & $(0.0251)$ \\
\hline \multirow[t]{2}{*}{ job rotation } & & $0.4328 * * *$ & & $0.3933 * * *$ \\
\hline & & $(0.0301)$ & & $(0.0328)$ \\
\hline \multirow[t]{2}{*}{ quality circles } & & $0.1866^{* * *}$ & & $0.1429 * * *$ \\
\hline & & $(0.0411)$ & & $(0.0394)$ \\
\hline \multirow[t]{2}{*}{ self learning } & & $0.1621 * * *$ & & $0.1304 * * *$ \\
\hline & & $(0.0418)$ & & $(0.0408)$ \\
\hline \multirow[t]{2}{*}{ training plan } & & & $0.1693 * * *$ & $0.1482 * * *$ \\
\hline & & & $(0.0243)$ & $(0.0250)$ \\
\hline \multirow[t]{2}{*}{ training budget } & & & -0.0208 & -0.0186 \\
\hline & & & $(0.0259)$ & $(0.0259)$ \\
\hline \multirow[t]{2}{*}{ workers' satisfaction } & & & -0.0009 & 0.0018 \\
\hline & & & $(0.0106)$ & $(0.0107)$ \\
\hline \multirow[t]{2}{*}{ learning achievements } & & & $0.0331 * * *$ & $0.0276^{* *}$ \\
\hline & & & $(0.0109)$ & $(0.0113)$ \\
\hline \multirow[t]{2}{*}{ trainees' performance } & & & $0.0687 * * *$ & $0.0557 * * *$ \\
\hline & & & $(0.0108)$ & $(0.0109)$ \\
\hline \multirow[t]{2}{*}{ training clauses } & & & $-0.0506^{*}$ & $-0.0543 * *$ \\
\hline & & & $(0.0272)$ & $(0.0276)$ \\
\hline \multirow[t]{2}{*}{ trade unions involvement } & & & 0.0008 & -0.0110 \\
\hline & & & $(0.0242)$ & $(0.0238)$ \\
\hline \multirow[t]{2}{*}{ _cons } & 0.2411 & -0.115 & -0.4013 & $-0.6556^{*}$ \\
\hline & $(0.3203)$ & $(0.3548)$ & $(0.3531)$ & $(0.3772)$ \\
\hline athrho & $-0.3920 * * *$ & $-0.2868^{*}$ & $-0.3058 * *$ & -0.2048 \\
\hline & $(0.146)$ & $(0.1589)$ & $(0.150)$ & $(0.1589)$ \\
\hline Industrial dummies & Yes & Yes & Yes & Yes \\
\hline $\mathrm{N}$ & 14884 & 14884 & 14884 & 14884 \\
\hline chi2 & 90.11 & 317.97 & 224.13 & 418.85 \\
\hline
\end{tabular}

Standard errors in parentheses

${ }^{*} p<0.10,{ }^{* *} p<0.05,{ }^{* * *} p<0.01$ 
Table 7 - On-the-job training propensity scores of temporary, part-time and unskilled workers

\begin{tabular}{cccccc}
\hline Variable & & N & ATT & s.e. & t-stat \\
\hline Unskilled & Treated & 1833 & 0.0430 & 0.0133 & 2.96 \\
& Controls & 4102 & & & \\
Temporary & & & & \\
& Treated & 2400 & 0.0166 & 0.0187 & 0.89 \\
& Controls & 3586 & & & \\
Part-time & Treated & 1867 & 0.0065 & 0.0216 & \\
& Controls & 4119 & & & \\
& & & & \\
\end{tabular}

Propensity scores are estimated through a logistic function by using a kernel matching algorithm. The function includes the covariates reported in Table 8 as controls

Table 8 - Quality of matching procedure. Treatment: Presence of unskilled workers

\begin{tabular}{ccccccc}
\hline \multicolumn{2}{c}{ Mean } & \multicolumn{3}{c}{ T test } \\
\hline Variable & Treated & Control & \%bias & $\mathbf{t}$ & $\mathbf{p}>|\mathbf{t}|$ & $\mathbf{V}(\mathbf{T}) / \mathbf{V}(\mathbf{C})$ \\
immigrants & 0.66067 & 0.65869 & 0.4 & 0.13 & 0.9 &. \\
size & 1.9645 & 1.9402 & 3.1 & 0.9 & 0.369 & 0.98 \\
part-time & 0.8287 & 0.82278 & 1.4 & 0.47 & 0.637 &. \\
temporary & 0.80306 & 0.78904 & 3.1 & 1.05 & 0.292 &. \\
training cost/ & & & & & & \\
hour (log) & 52.333 & 52.077 & 0.8 & 0.25 & 0.806 & 1.07 \\
labour costs & 36090 & 35871 & 1.4 & 0.47 & 0.638 & $1.13^{*}$ \\
males & 0.42171 & 0.43382 & 2.5 & 0.74 & 0.459 &. \\
construction & 0.21331 & 0.2252 & 2.9 & 0.87 & 0.385 &. \\
retail & 0.13257 & 0.12801 & 1.3 & 0.41 & 0.682 &. \\
finance & 0.05019 & 0.04495 & 2 & 0.75 & 0.456 &. \\
age $>55$ & 0.27778 & 0.27325 & 1.9 & 0.6 & 0.551 & 1.07 \\
age $<25$ & 0.06401 & 0.06508 & 1.2 & 0.37 & 0.714 & $0.91^{*}$ \\
\hline
\end{tabular}


Table 9 - Determinants of off-the job training variety

\begin{tabular}{|c|c|c|c|}
\hline & ginicont & ginicont & ginicont \\
\hline \multirow[t]{2}{*}{ part time } & -0.015 & -0.012 & -0.016 \\
\hline & $(0.012)$ & $(0.012)$ & $(0.012)$ \\
\hline \multirow[t]{2}{*}{ temporary workers } & $-0.045 * * *$ & $-0.044 * * *$ & $-0.039 * * *$ \\
\hline & $(0.012)$ & $(0.012)$ & $(0.011)$ \\
\hline \multirow[t]{2}{*}{ immigrants } & -0.001 & -0.001 & -0.006 \\
\hline & $(0.012)$ & $(0.012)$ & $(0.012)$ \\
\hline \multirow[t]{2}{*}{ training cost/ hour (log) } & 0.010 & 0.008 & 0.012 \\
\hline & $(0.010)$ & $(0.010)$ & $(0.010)$ \\
\hline \multirow[t]{2}{*}{ size } & $(0.101)^{* * *}$ & $-0.094 * * *$ & $-0.081 * * *$ \\
\hline & $(0.006)$ & $(0.006)$ & $(0.007)$ \\
\hline \multirow[t]{2}{*}{ unskilled } & -0.013 & -0.008 & -0.009 \\
\hline & $(0.013)$ & $(0.013)$ & $(0.013)$ \\
\hline \multirow[t]{2}{*}{ Age $>55$} & $0.149 *$ & $0.142 *$ & $0.137 *$ \\
\hline & $(0.067)$ & $(0.066)$ & $(0.066)$ \\
\hline \multirow[t]{2}{*}{ Age $<25$} & $0.167 * *$ & $0.173 * *$ & $0.153 * *$ \\
\hline & $(0.059)$ & $(0.057)$ & $(0.052)$ \\
\hline \multirow[t]{2}{*}{ females } & 0.04 & 0.033 & 0.034 \\
\hline & $(0.028)$ & $(0.028)$ & $(0.027)$ \\
\hline \multirow[t]{2}{*}{ innovativeness } & $-0.054 * * *$ & $-0.040 * * *$ & $-0.043 * * *$ \\
\hline & $(0.012)$ & $(0.012)$ & $(0.012)$ \\
\hline \multirow[t]{2}{*}{ job rotation } & & $-0.081 * * *$ & \\
\hline & & $(0.016)$ & \\
\hline \multirow[t]{2}{*}{ quality circles } & & $-0.095 * * *$ & \\
\hline & & $(0.021)$ & \\
\hline \multirow[t]{2}{*}{ self learning } & & $-0.068 * * *$ & \\
\hline & & $(0.019)$ & \\
\hline \multirow[t]{2}{*}{ training plan } & & & $-0.086 * * *$ \\
\hline & & & $(0.013)$ \\
\hline \multirow[t]{2}{*}{ training budget } & & & -0.027 \\
\hline & & & $(0.014)$ \\
\hline \multirow[t]{2}{*}{ workers' satisfaction } & & & -0.006 \\
\hline & & & $(0.005)$ \\
\hline \multirow[t]{2}{*}{ learning achievements } & & & -0.006 \\
\hline & & & $(0.006)$ \\
\hline \multirow[t]{2}{*}{ trainees' performance } & & & -0.009 \\
\hline & & & $(0.006)$ \\
\hline \multirow[t]{2}{*}{ training clauses } & & & 0.006 \\
\hline & & & $(0.014)$ \\
\hline \multirow[t]{2}{*}{ trade unions involvement } & & & 0.006 \\
\hline & & & $(0.012)$ \\
\hline \multirow[t]{2}{*}{ _cons } & $0.827 * * *$ & $0.841 * * *$ & $0.873 * * *$ \\
\hline & $(0.045)$ & $(0.045)$ & $(0.044)$ \\
\hline Industrial dummies & Yes & Yes & Yes \\
\hline $\mathrm{N}$ & 5986 & 5986 & 5986 \\
\hline $\mathrm{R} 2$ & 0.114 & 0.135 & 0.156 \\
\hline
\end{tabular}

Standard errors in parentheses

${ }^{*} p<0.10,{ }^{* *} p<0.05,{ }^{* * *} p<0.01$ 
Table 10 - Determinants of the number of job-related practices (zero-inflated Poisson regression) - marginal effects

\begin{tabular}{|c|c|c|c|}
\hline & $\begin{array}{c}(1) \\
\text { agg_jbp }\end{array}$ & $\begin{array}{c}(2) \\
\text { agg_jbp }\end{array}$ & $\begin{array}{c}(3) \\
\text { agg_jbp }\end{array}$ \\
\hline \multirow[t]{2}{*}{ part time } & $0.126 * *$ & $0.132 * * *$ & $0.131 * * *$ \\
\hline & $(0.038)$ & $(0.036)$ & $(0.035)$ \\
\hline \multirow[t]{2}{*}{ temporary } & 0.056 & 0.038 & 0.039 \\
\hline & $(0.034)$ & $(0.033)$ & $(0.033)$ \\
\hline \multirow[t]{2}{*}{ immigrants } & -0.042 & -0.029 & -0.027 \\
\hline & $(0.032)$ & $(0.031)$ & $(0.031)$ \\
\hline \multirow[t]{2}{*}{ training cost/ hour $(\log )$} & -0.048 & -0.033 & -0.034 \\
\hline & $(0.033)$ & $(0.032)$ & $(0.032)$ \\
\hline \multirow[t]{2}{*}{ size } & $0.100 * *$ & $0.067 * * *$ & $0.073 * * *$ \\
\hline & $(0.049)$ & $(0.017)$ & $(0.018)$ \\
\hline \multirow[t]{2}{*}{ unskilled } & $0.149 * * *$ & $0.128 * * *$ & $0.129 * * *$ \\
\hline & $(0.032)$ & $(0.031)$ & $(0.031)$ \\
\hline \multirow[t]{2}{*}{ labour cost/hour $(\log )$} & $0.004^{*}$ & $0.004 * *$ & $0.004 * *$ \\
\hline & $(0.002)$ & $(0.002)$ & $(0.002)$ \\
\hline \multirow[t]{2}{*}{ age $>55$} & -0.400 & -0.254 & -0.246 \\
\hline & $(0.362)$ & $(0.260)$ & $(0.261)$ \\
\hline \multirow[t]{2}{*}{ age $<25$} & 0.053 & 0.075 & 0.060 \\
\hline & $(0.189)$ & $(0.205)$ & $(0.200)$ \\
\hline \multirow[t]{2}{*}{ females } & -0.114 & -0.055 & -0.059 \\
\hline & $(0.123)$ & $(0.076)$ & $(0.075)$ \\
\hline \multirow[t]{2}{*}{ innovativeness } & $0.345 * * *$ & $0.273 * * *$ & $0.274 * * *$ \\
\hline & $(0.035)$ & $(0.031)$ & $(0.031)$ \\
\hline \multirow[t]{2}{*}{ training plan } & & $0.295 * * *$ & $0.299 * * *$ \\
\hline & & $(0.037)$ & $(0.036)$ \\
\hline \multirow[t]{2}{*}{ training budget } & & $0.085 *$ & 0.086 \\
\hline & & $(0.037)$ & $(0.035)$ \\
\hline \multirow[t]{2}{*}{ workers' satisfaction } & & $0.055 * * *$ & 0.056 \\
\hline & & $(0.014)$ & $(0.014)$ \\
\hline \multirow[t]{2}{*}{ learning achievements } & & $0.041 * *$ & 0.042 \\
\hline & & $(0.015)$ & $(0.014)$ \\
\hline \multirow[t]{2}{*}{ workers' performance } & & $0.070 * * *$ & 0.070 \\
\hline & & $(0.014)$ & $(0.014)$ \\
\hline \multirow[t]{2}{*}{ contract clauses } & & & -0.046 \\
\hline & & & $(0.032)$ \\
\hline \multirow[t]{2}{*}{ trade unions } & & & -0.009 \\
\hline & & & $(0.029)$ \\
\hline \multirow[t]{2}{*}{ _cons } & -0.183 & $-0.663 * * *$ & $-0.673 * * *$ \\
\hline & $(0.207)$ & $(0.148)$ & $(0.136)$ \\
\hline Industrial dummies & Yes & Yes & Yes \\
\hline $\mathrm{N}$ & 5914.000 & 5914.000 & 5914.000 \\
\hline chi2 & 476.372 & 765.332 & 783.332 \\
\hline
\end{tabular}

Standard errors in parentheses

${ }^{*} p<0.10,{ }^{* *} p<0.05,{ }^{* * *} p<0.01$ 


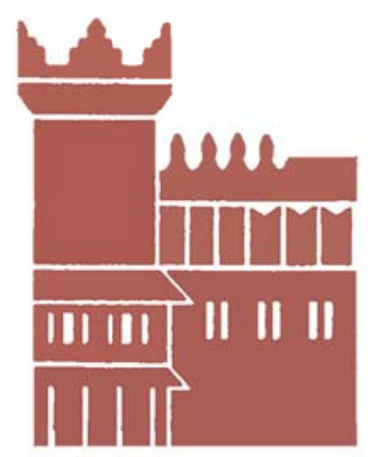

Alma Mater Studiorum - Università di Bologna DEPARTMENT OF ECONOMICS

Strada Maggiore 45

40125 Bologna - Italy

Tel. +39051 2092604

Fax +390512092664

http://www.dse.unibo.it 